\title{
STUDI KOMPARATIF USAHATANI PADI SEMI ORGANIK DAN KONVENSIONAL DI DESA WATUKEBO KECAMATAN BLIMBINGSARI KABUPATEN BANYUWANGI
}

\author{
Ani Domiah ${ }^{1}$ dan Jani Januar ${ }^{2}$ \\ ${ }^{1}$ Mahasiswa Program Studi Agribisnis Fakultas Pertanian Universitas Jember \\ ${ }^{2}$ Staf Pengajar Program Studi Agribisnis Fakultas Pertanian Universitas Jember \\ email: anidomiah17@gmail.com
}

\begin{abstract}
The rising of semi-organic rice farming in Watukebo Village is due to the doubthness in implementing the semi-organic system. Semi-organic rice farm system require considerable cost savings compared to conventional rice and in the short-term, semi-organic rice production will generally decline. The study was conducted in the Watukebo Village Banyuwangi Regency intentionally. The sample are taken by using total sampling method for semi-organic rice farmers and quota sampling technique for conventional rice farmers. The data used are primary data and secondary data. The Tools of analysis data used are income analysis, $R / C$ ratio analysis, and Cobb-Douglas production function analysis. The results showed that: (1) there was no significant difference between the average income of semi-organic rice farmers and conventional rice farmers, (2) there was no significant difference between the average of cost efficiency of semi-organic rice farming with conventional rice farmers in Watukebo of Blimbingsari, and (3) factors that influence the production of semi organic rice significantly are land area, organic fertilizer, and urea fertilizer. Factors affecting the conventional rice production significantly are the number of seeds and labors.
\end{abstract}

Keywords : Semi Organic, Conventional Rice, Cobb-Douglas Production Function, Cost Efficiency, Income Analysis

\section{PENDAHULUAN}

Pertanian organik merupakan solusi yang dapat menjawab gerakan revolusi hijau yang dicanangkan pemerintah Indonesia pada tahun 1960-an. Gerakan tersebut telah menyebabkan penurunan tingkat kesuburan tanah secara drastis serta peningkatan kerusakan lingkungan akibat penggunaan pupuk kimia dan pestisida kimia yang tidak terkendali. Sistem pertanian berbasis high input energy seperti pupuk dan pestisida kimia dapat merusak kesuburan tanah yang pada akhirnya menyebabkan terjadinya penurunan kualitas produk pertanian yang dihasilkan sehingga muncul gerakan sistem pertanian organik yang menggunakan input produksi alamiah tanpa bahan kimia yang memicu kerusakan lingkungan. (Mayrowani, 2012).

Penerapan metode bertanam secara organik di Indonesia mulai dikenal pada pertengahan tahun 1980-an. Guna menunjang pembangunan ekonomi yang berkelanjutan, terutama dalam bidang pertanian dan pangan, pemerintah mencetusan program "Go Organic 2010" den- gan tujuan untuk mencapai ketahanan pangan pangan domestik serta menjadi salah satu negara produsen organik terbesar di dunia. Penerapan sistem pertanian organik dapat memberikan solusi terhadap masalah penurunan produkivitas lahan pertanian di Indonesia. Menurut berbagai praktisi di bidang organic farming, produktivitas lahan petanian organik dalam jangka panjang lebih tinggi dibandingkan lahan konvensional, namun barriers to entry dalam memulai pertanian organik lebih besar, antara lain dalam hal biaya konversi lahan yang memakan waktu sekitar 2 tahun, biaya sertifikasi yang cukup mahal serta komponen labor cost untuk pencegahan hama yang lebih tinggi. (Herawati dkk., 2014).

Menurut IFOAM (International Federation of Organic Agriculture Movements) dalam Kusumo dkk. (2017), Berbagai kebijakan telah dicanangkan oleh pemerintah dalam pengembangan pertanian organik di Indonesia melalui beberapa kegiatan antara lain pengembangan teknologi pertanian organik, pembentukan kelompok tani organik serta strategi pemasaran pro- 
duk organik dengan harapan Indonesia menjadi produsen produk organik yang dapat bersaing di tingkat dunia. Indonesia termasuk salah satu Negara yang masuk dalam The Ten Countries with The Largest Organic Area 2012 di kawasan asia. Sebagian besar lahan organik yang ada di Indonesia tersebar di Pulau Jawa dan digunakan untuk mengusahakan tanaman padi organik, sayuran organik hingga kopi oganik.

Menurut Khorniawati (2014), peningkatan kesadaran masyarakat tehadap bahaya kandungan zat kimia dalam produk pertanian menjadikan produk pertanian organik mulai diminati konsumen. Menurut Kementerian pertanian dalam Safitri (2013), komoditas padi organik menempati posisi pertama dalam capaian produksi pertanian organik Indonesia dalam kurun waktu 2008 hingga 2015 dengan rata-rata jumlah produksi sebesar 1.666.250 Ton, disusul kemudian komoditas sayuran organik dengan produksi sebesar 221.027 Ton. Komoditas pertanian organik lainnya terdiri dari kakao organik (56.323 Ton), kedelai organik (23.875 Ton), kopi organik (19.407 Ton), dan teh organik (1.180 Ton).

Menurut Siahaan dalam Mungara dkk. (2013), sentra produksi padi organik paling banyak berlokasi di Pulau Jawa yaitu Jawa Tengah, Jawa Timur, Jawa Barat, dan Yogyakarta. Kabupaten Banyuwangi merupkan salah satu daerah pengembangan padi organik di Provinsi Jawa timur yang telah berhasil mendaftarkan varietas padi organik di Kementrian Pertanian Indonesia. Menurut Kompas.com (2016), Kebupaten Banyuwangi memiliki tiga varietas padi organik yang berhasil didaftarkan yaitu beras merah varietas Blambangan $\mathrm{A} 3$, beras merah varietas hitam melik A3, dan beras putih varietas SOJ A3 pada 18 November tahun 2016. Ketiga varietas tersebut telah dikembangan di beberapa kecamatan yang ada di Banyuwangi.

Pengembangan padi organik di Kabupaten Banyuwangi telah dilakukan di tujuh kecamatan yaitu Kecamatan Singojuruh, Rogojampi, Songgon, Sempu, Licin, Glenmore, dan Kalibaru. Menurut Dinas Pertanian Kabupaten Banyuwangi, hanya ada dua kecamatan yang telah mendapatkan sertifikat prima 3 dan LeSOS yaitu Kecamatan Singojuruh Desa Sumberbaru dan Kecamatan Rogojampi Desa Watukebo. Masing-masing desa tersebut memiliki kelompok tani yang telah tersertifikasi organik yaitu Kelompok Tani Sumber Urip di Desa Watukebo dan Kelompok Tani Mendo Sampurno di Desa
Sumberbaru. Perkembangan Kelompok Tani Sumber Urip memerlukan perhatian yang serius, hal tersebut dikarenakan anggota Kelompok Tani Sumber Urip merasa ragu-ragu dalam melanjutkan sistem pertanian organik sehingga terdapat petani yang memutuskan untuk kembali ke sistem konvensional.

Penerapan usahatani padi organik oleh anggota Kelompok Tani Sumber Urip dilakukan secara bertahap melalui masa transisi (semi organik) dan telah dimulai pada tahun 2012, namun tidak semua anggota kelompok beralih dari sistem konvensional ke semi organik. Menurut Heryanto dkk. (2016), produktivitas pertanian organik pada tahap awal akan mengalami penurunan namun akan semakin meningkat seiring waktu, sedangkan produktivitas pertanian sistem konvensional akan cenderung menurun dalam jangka panjang sebab tanah akan mengalami kemiskinan unsur hara akibat rendahnya kandungan bahan organik. Selain masalah produktivitas, perbedaan mendasar dari sistem usahatani padi organik dan kovensional adalah dari komponen biaya yang dikeluarkan. Unsur pembiayaan yang digunakan dalam usahatani padi organik dan konvensional tentu saja berbeda, hal tersebut dikarenakan sarana produksi yang digunakan kedua jenis usahatani tersebut berbeda sehingga akan mempengaruhi besarnya biaya yang dikeluarkan. hal tersebut didukung oleh penelitian Menurut Lesmana dan Margareta (2017), pertanian organik tidak meningkatkan hasil per satuan luas, bahkan cenderung menurun dari waktu ke waktu apabila tidak diaplikasikan secara tepat.

Berdasarkan latar belakang tersebut penelitian ini bertujuan untuk mengetahui : (1) perbedaan pendapatan antara petani padi sistem semi organik dan petani padi konvensional di Desa Watukebo Kecamatan Blimbingsari Kabupaten Banyuwangi, (2) perbedaan efisiensi biaya usahatani antara petani padi sistem semi organik dan petani padi sistem konvensional di Desa Watukebo Kecamatan Blimbingsari Kabupaten Banyuwangi, dan (3) faktor-faktor yang mempengaruhi produksi padi semi organik dan konvensional di Desa Watukebo Kecamatan Blimbingsari Kabupaten Banyuwangi.

\section{METODE PENELITIAN}

Penentuan daerah penelitian dilakukan secara purposive method. Menurut Zuriah (2005), purposive methode merupakan teknik pemilihan 
lokasi yang pemilihannya didasarkan pada tujuan spesifik penelitian dan diketahui oleh peneliti sejak awal. Penelitian dilakukan di Desa Watukebo dengan dasar pertimbangan bahwa desa tersebut memiliki Kelompok Tani Sumber Urip yang telah tersertifikasi padi semi organik prima 3, namun saat ini perkembangannya membutuhkan perhatian karena anggota kelompok tani yang menerapkan sistem semi organik raguragu dalam melanjutkan masa peralihan usahataninya.

Penelitian ini menggunakan metode analitik dan deskriptif. Metode analitik merupakan metode yang berfungsi untuk menguji hipotesa-hipotesa dan mengadakan interpretasi terhadap hasil analisa. Metode deskriptif merupakan metode yang bertujuan untuk mendeskripsikan secara sistematis, faktual, dan akurat mengenai fakta dan sifat populasi tertentu. Data yang telah diperoleh kemudian dianalisis dan diinterpretasikan secara deskriptif untuk mengetahui perbedaan biaya dan efisiensi usahatani serta faktor-faktor produksi apa saja yang mempengaruhi usahatani padi semi organik dan konvensional.

Sampel yang digunakan dalam penelitian menggunakan metode total sampling unuk petani padi semi organik dan quota sampling untuk petani padi konvensional. Total sampling merupakan salah satu teknik pengambilan sampel yang menggunakan seluruh populasi untuk dijadikan sampel, sedangkan quota sampling merupakan teknik pengambilan sampel dari suatu populasi yang memiliki ciri tertentu dengan penentuan jumlah sampel berdasarkan jumlah kuota yang diinginkan. Jumlah sampel yang dipilih sebanyak 76 petani yang terdiri dari 31 petani padi semi organik dan 31 petani padi konvensional.

Metode penelitian yang digunakan dalam penelitian ini adalah wawancara terstruktur dan dokumentasi. Wawancara terstruktur artinya wawancara yang dilakukan dengan berdasarkan pada daftar pertanyaan yang telah disusun secara sistematis sebagai panduan pedoman. Metode dokumentasi merupakan metode yang digunakan untuk menelusuri data historis. Wawancara terstruktur digunakan untuk memperoleh data primer. Metode dokumentasi digunakan untuk memperoleh data sekunder. Data sekunder dalam penelitian ini bersumber dari Dinas Pertanian Kabupaten Banyuwangi dan data statistik yang diterbitkan secara berkala oleh Badan Pusat Statistik.
Untuk menjawab rumusan masalah mengenai perbedaan pendapatan petani padi semi organik dan konvensional di Desa Watunm m n kebo Kecamatan Blimbingsari Kabupaten Banyuwangi, terlebih dahulu dilakukan analisis terhadap pendapatan masing-masing usahatani dengan rumus sebagai berikut (Soekartawi, 1995) :

$$
\begin{array}{ll}
\pi & =\mathrm{TR}-\mathrm{TC} \\
\mathrm{TR} & =\mathrm{P} \times \mathrm{Q} \\
\mathrm{TC} & =\mathrm{TFC}+\mathrm{TVC}
\end{array}
$$

Keterangan :

$$
\begin{array}{ll}
\pi & =\text { Total Pendapatan }(\mathrm{Rp} / \mathrm{Ha}) \\
\mathrm{TR} & =\text { Total Penerimaan }(\mathrm{Rp} / \mathrm{Ha}) \\
\mathrm{TC} & =\text { Tota Biaya }(\mathrm{Rp} / \mathrm{Ha}) \\
\mathrm{P} & =\text { Harga Output }(\mathrm{Rp} / \mathrm{Kg}) \\
\mathrm{Q} & =\text { Hasil Produksi }(\mathrm{Kg} / \mathrm{Ha}) \\
\mathrm{TFC} & =\text { Total Biaya Tetap }(\mathrm{Rp} / \mathrm{Ha}) \\
\mathrm{TVC} & =\text { Total Biaya Variabel }(\mathrm{Rp} / \mathrm{Ha})
\end{array}
$$

Langkah selanjutnya, untuk menguji perbedaan pendapatan petani semi organik dan konvensional digunakan uji beda dua sampel bebas. Menurut Sugiyono (2013), uji independent sample t-test merupakan uji yang digunakan untuk menguji hipotesis komparatif dua sampel bebas serta untuk mengetahui secara statistik apakah terdapat perbedaan yang nyata terhadap pendapatan petani padi semi organik dan konvensional. Berikut ini merupakan rumus yang digunakan untuk mencari thitung :

$$
\mathrm{t}=\frac{\overline{x_{1}}-\overline{x_{2}}}{\sqrt{\frac{\left(n_{1}-n_{2}\right)^{s_{1}}{ }^{2}+\left(n_{2}-1\right) s_{2}{ }^{2}}{n_{1}+n_{2}-2}+\left(\frac{1}{n_{1}}+\frac{1}{n_{2}}\right)}}
$$

\section{Keterangan :}

$\mathrm{x}_{1}=$ Rata-rata pendapatan petani semi organik

$\mathrm{x}_{2}=$ Rata-rata pendapatan petani konvensional

$\mathrm{n}_{1}=$ Jumlah petani semi organik

$\mathrm{n}_{2}=$ Jumlah petani konvensional

$\mathrm{s}_{1}=$ Standar deviasi petani semi organik

$\mathrm{s}_{2}=$ Standar deviasi petani konvensional

Kriteria uji independent sampel t test :

1. Apabila nilai $\mathrm{t}_{\text {hitung }}>\mathrm{t}_{\text {tabel }}$ atau $-\mathrm{t}_{\text {hitung }}<-\mathrm{t}_{\text {tabel }}(\alpha$ $=0,05)$, maka $\mathrm{H}_{0}$ ditolak

2. Apabila nilai $-\mathrm{t}_{\text {tabel }} \leq \mathrm{t}_{\text {hitung }} \leq \mathrm{t}_{\text {tabel }}(\alpha=0,05)$, maka $\mathrm{H}_{0}$ diterima

Keterangan :

$\mathrm{H}_{0}$ : Tidak terdapat perbedaan yang nyata/ signifikan antara pendapatan padi semi organik dan petani padi konvensional di Desa Watukebo.

$\mathrm{H}_{1}$ : Terdapat perbedaan yang nyata/sig- 
nifikan antara rata-rata biaya usahatani padi semi organik dan usahatani padi konvensional di Desa Watukebo.

Untuk menjawab rumusan masalah mengenai perbedaan efisiensi biaya usahatani padi semi organik dan konvensional di Desa Watukebo Kecamatan Blimbingsari Kabupaten Banyuwangi, terlebih dahulu dilakukan analisis terhadap pendapatan masing-masing usahatani dengan rumus :

Keterangan :

$$
\mathrm{R} / \mathrm{C}_{\text {ratio }}=\mathrm{TR} / \mathrm{TC}
$$

$$
\begin{array}{ll}
\mathrm{R} / \mathrm{C}_{\text {ratio }} & =\text { Efisiensi biaya usahatani } \\
\mathrm{TR} & =\text { Total penerimaan }(\mathrm{Rp} / \mathrm{Ha}) \\
\mathrm{TC} & =\text { Total Biaya }(\mathrm{Rp} / \mathrm{Ha})
\end{array}
$$

Penentuan efsiensi biaya usahatani dilakukan dengan kriteria sebagai berikut :

1. Apabila nilai $\mathrm{R} / \mathrm{C}_{\text {ratio }}$ lebih dari satu, maka usahatani menguntungkan dan layak untuk dijalankan.

2. Apabila nilai $R / C_{\text {ratio }}$ sama dengan satu, maka usahatani berada dalam titik impas.

3. Apabila nilai $\mathrm{R} / \mathrm{Cratio}$ kurang dari satu, maka usahatani merugikan sehingga tidak layak untuk dijalankan.

Langkah selanjutnya, untuk menguji perbedaan efisiensi biaya usahatani padi semi organik dan konvensional digunakan independent sample t-test dengan rumus :

$$
\mathrm{t}=\frac{\overline{x_{1}}-\overline{x_{2}}}{\sqrt{\frac{\left(n_{1}-n_{2}\right)^{2}{ }^{2}+\left(n_{2}-1\right) s_{2}{ }^{2}}{n_{1}+n_{2}-2}+\left(\frac{1}{n_{1}}+\frac{1}{n_{2}}\right)}}
$$

Keterangan :

$\overline{\mathrm{X}}_{1} \quad$ = Rata-rata tingkat efisiensi biaya usahatani padi semi organik

$\overline{\mathrm{x}_{2}} \quad$ = Rata-rata tingkat efisiensi biaya usahatani padi konvensional

$\mathrm{n}_{1}=$ Jumlah petani semi organik

$\mathrm{n}_{2}=$ Jumlah petani konvensional

$\mathrm{s}_{1}=$ Standar deviasi petani semi organik

$\mathrm{s}_{2}=$ Standar deviasi petani konvensional

Kriteria uji independent sampel t test :

1. Apabila nilai $t_{\text {hitung }}>t_{\text {tabel }}$ atau $-t_{\text {hitung }}<-t_{\text {tabel }}$ $(\alpha=0,05)$, maka $\mathrm{H}_{0}$ ditolak

2. Apabila nilai $-\mathrm{t}_{\text {tabel }} \leq \mathrm{t}_{\text {hitung }} \leq \mathrm{t}_{\text {tabel }}(\alpha=0,05)$, maka $\mathrm{H}_{0}$ diterima.

Keterangan :

$\mathrm{H}_{0} \quad$ : Tidak terdapat perbedaan yang nyata/signifikan antara rata-rata tingkat efisiensi biaya usahatani padi semi organik dengan usahatani padi konvensional di Desa
Watukebo.

$\mathrm{H}_{1}$ : Terdapat perbedaan yang nyata/signifikan antara rata-rata tingkat efisiensi biaya usahatani padi semi organik dengan usahatani padi konvensional di Desa Watukebo.

Untuk menjawab rumusan masalah ketiga tentang faktor-faktor yang mempengaruhi produksi padi semi organik dan konvensional di Desa Watukebo Kecamatan Blimbingsari Kabupaten Banyuwangi dianalisis menggunakan fungsi produksi Cobb-Douglas.

Faktor-faktor yang mempengaruhi produksi padi semi organik dituliskan dalam persamaan :

$$
\hat{y}=a x_{1}{ }^{b_{1}} x_{2}{ }^{b_{2}} x_{3}{ }^{b_{3}} x_{4}{ }^{b_{4}} x_{5}{ }^{b_{5}} x_{6}{ }^{b_{6}} x_{7}{ }^{b_{7}} e^{u}
$$

Persamaan tersebut kemudian ditransformasikan dalam bentuk logaritma (log) yang secara matematis dituliskan sebagai berikut:

$\log \hat{y}=\log a+b_{1} \log x_{1}+b_{2} \log x_{2}+b_{3} \log x_{3}+$ $\mathrm{b}_{4} \log \mathrm{x}_{4}+\mathrm{b}_{5} \log \mathrm{x}_{5}+\mathrm{b}_{6} \log \mathrm{x}_{6}+\mathrm{b}_{7} \log \mathrm{x}_{7}+$ $\mathrm{v}$

Keterangan :

$$
\begin{aligned}
& \hat{\mathrm{y}} \quad=\text { Produksi }(\mathrm{kg}) \\
& \mathrm{a} \quad=\text { Konstanta } \\
& \mathrm{b}_{1} ; \mathrm{b}_{2} ; \mathrm{b}_{3} ; \ldots ; \mathrm{b}_{7}=\text { Koefisien regresi } \\
& \mathrm{x}_{1} \quad=\text { Luas lahan }(\mathrm{Ha}) \\
& \mathrm{x}_{2} \quad=\text { Jumlah benih }(\mathrm{kg}) \\
& \mathrm{x}_{3} \quad=\text { Pupuk urea }(\mathrm{Kg}) \\
& \mathrm{x}_{4} \quad=\text { Pupuk phonska }(\mathrm{kg}) \\
& \mathrm{x}_{5} \quad=\text { Pupuk organik }(\mathrm{kg}) \\
& \mathrm{x}_{6} \quad=\text { Agensia hayati (liter) } \\
& \mathrm{x}_{7} \quad=\text { Tenaga kerja (HKP) } \\
& \mathrm{e}^{\mathrm{u}} \quad=\text { Kesalahan penggunaan }
\end{aligned}
$$

Sedangkan faktor-faktor yang mempengaruhi produksi padi kovensional yang dituliskan dalam persamaan berikut :

$$
\hat{\mathrm{y}}=\mathrm{ax}_{1}{ }^{\mathrm{b}_{1}} x_{2}{ }^{\mathrm{b}_{2}} \mathrm{x}_{3}{ }^{\mathrm{b}_{3}} \mathrm{x}_{4}{ }^{\mathrm{b}_{4}} x_{5}{ }^{\mathrm{b}_{5}} \mathrm{e}^{\mathrm{u}}
$$

Persamaan tersebut kemudian ditransformasikan dalam bentuk logaritma (log) sebagai berikut :

$\log \hat{y}=\log a+b_{1} \log x_{1}+b_{2} \log x_{2}+b_{3} \log x_{3}+$ $\mathrm{b}_{4} \log \mathrm{x}_{4}+\mathrm{b}_{5} \log \mathrm{x}_{5}+\mathrm{v}$

Keterangan :

$$
\begin{array}{ll}
\hat{\mathrm{y}} & =\text { Produksi }(\mathrm{kg}) \\
\mathrm{a} & =\text { Konstanta } \\
\mathrm{b}_{1} ; \mathrm{b}_{2} ; \mathrm{b}_{3} ; \mathrm{b}_{4} ; \mathrm{b}_{5} & =\text { Koefisien regresi } \\
\mathrm{x}_{1} & =\text { Luas lahan }(\mathrm{Ha}) \\
\mathrm{x}_{2} & =\text { Jumlah benih }(\mathrm{kg}) \\
\mathrm{x}_{3} & =\text { Pupuk kimia }(\mathrm{Kg}) \\
\mathrm{x}_{4} & =\text { Pestisida (liter) } \\
\mathrm{x}_{5} & =\text { Tenaga Kerja }(\mathrm{HKP}) \\
\mathrm{e}^{\mathrm{u}} & =\text { Kesalahan penggunaan }
\end{array}
$$


1. Langkah selanjutnya untuk mengetahui tingkat ketepatan model digunakan koefisien determinasi $\left(\mathrm{R}^{2}\right)$ yang dirumuskan sebagai berikut :

$$
\mathrm{R}^{2}=\frac{\text { Jumlah kuadrat regresi }}{\text { Jumlah kuadrat total terkoreksi }}
$$

Nilai $R^{2}$ berkisar antara 0 - 1 . Semakin besar nilai $\mathrm{R}^{2}$ (mendekai 1) maka ketepatan variabel x semakin baik dalam menggambarkan variabel $\hat{y}$.

2. Langkah selanjutnya adalah untuk mengetahui pengaruh variabel independen secara bersama-sama terhadap variabel dependen digunakan uji $\mathrm{F}$ dengan rumus sebagai berikut :

$$
\mathrm{F}_{\text {hitung }}=\frac{\text { Kuadran tengah regresi }}{\text { Kuadran tengah sisa }}
$$

Kriteria pengambilan keputusan :

a. $\mathrm{F}_{\text {hitung }}>\mathrm{F}_{\text {tabel }}(\alpha=0,05)$ maka $\mathrm{H}_{0}$ ditolak, yang artinya secara keseluruhan variabel $\mathrm{x}$ berpengaruh nyata terhadap variabel produksi $\hat{y}$.

b. $\mathrm{F}_{\text {hitung }}<\mathrm{F}_{\text {tabel }}(\alpha=0,05)$ maka $\mathrm{H}_{0}$ diterima, yang artinya secara keseluruhan variabel $\mathrm{x}$ tidak berpengaruh nyata terhadap variabel ŷ (produksi).

3. Langkah selanjutnya adalah mengetahui pengaruh masing-masing variabel bebas terhadap variabel terikat sehingga dilakukan uji $t$ dengan rumus sebagai berikut:

$$
\begin{gathered}
\mathrm{t}_{\text {hitung }}=\left|\frac{\left[\mathrm{b}_{\mathrm{i}}\right]}{\left[\mathrm{Sb}_{\mathrm{i}}\right]}\right| \\
\mathrm{Sb}_{\mathrm{i}}=\sqrt{\frac{\text { Jumlah Kuadran Sisa }}{\text { Jumlah Kuadran Tengah Sisa }}}
\end{gathered}
$$

Keterangan :

$b_{i} \quad=$ Koefisien regresi ke-i

$\mathrm{Sb}_{\mathrm{i}}=$ Standar deviasi ke-i

Kriteria pengambilan keputusan :

a. $\mathrm{t}_{\text {hitung }}>\mathrm{t}_{\text {tabel }}(\alpha=0,05)$ maka $\mathrm{H}_{0}$ ditolak, yang artinya secara parsial variabel $x$ berpengaruh nyata terhadap variabel $\hat{y}$ (produksi).

b. $\mathrm{t}_{\text {hitung }}<\mathrm{t}_{\text {tabel }}(\alpha=0,05)$ maka $\mathrm{H}_{0}$ diterima, yang artinya secara parsial variabel $\mathrm{x}$ tidak berpengaruh secara nyata terhadap variabel ŷ (produksi).

Selain itu juga dilakukan uji asumsi klasik pada model regresi sebagai berikut :
1. Uji Normalitas, untuk menguji apakah model regresi yang diperoleh telah terdistribusi normal atau belum. Kriteria pengujian uji normalitas dapat dilakukan dengan melihat grafik P-Plot dimana dalam grafik tersebut terdapat titik-titik yang menyebar dan mengikuti sepanjang garis diagonal.

2. Uji Heteroskedastisitas, digunakan untuk mengetahui adanya gejala residu dari suatu pengamatan regresi berubah-ubah pada suatu rentang data tertentu. Adanya gejala heteroskedastisitas dalam model regresi dapat dilihat dengan adanya titik-titik yang membentuk pola tertentu pada grafik scatter plot.

3. Uji Multikolinearitas, digunakan untuk menguji ada tidaknya hubungan yang sempurna antar variabel bebas dalam model regresi. Uji multikolinearitas dapat dilakukan dengan melihat nilai variance inflation factor (VIF). Apabila nilai VIF > 10 maka terjadi multikolinearitas dalam model regresi.

4. Uji Autokorelasi, digunakan untuk mengetahui $t$ korelasi antara kesalahan pengganggu pada periode $t$ dengan periode $t-1$ sehingga lebih relevan digunakan untuk data time series.

\section{HASIL DAN PEMBAHASAN}

Perbedaan Pendapatan Petani Padi Sistem Semi Organik dan Petani Padi Sistem Konvensional di Desa Watukebo Kecamatan Blimbingsari Kabupaten Banyuwangi

Pendapatan merupakan keuntungan bersih yang didapatkan petani padi selama satu kali musim tanam. Satu kali musim tanam padi umumnya membutuhkan waktu selama empat bulan. Nilai pendapatan petani padi diperoleh dari selisih total penerimaan yang diperoleh petani padi dengan total biaya yang dikeluarkan. Total penerimaan didapatkan dari hasil perkalian produksi padi dalam satuan kilogram dengan harga jual. Total biaya yang dikeluarkan petani terdiri dari biaya tetap dan biaya variabel. Biaya variabel pada usahatani padi semi organik terdiri dari biaya benih, pupuk kimia, pupuk organik, agensia hayati, dan tenaga kerja. Sedangkan biaya variabel pada usahatani padi konvensional terdiri dari biaya benih, pupuk kimia, obat-obatan, dan tenaga kerja. Biaya tetap pada kedua sistem usahatani tersebut meliputi biaya sewa lahan dan penyusutan peralatan. Perhitungan pendapatan kedua usahatani tersebut dapat dilihat dalam Tabel 1 . 
Berdasarkan Tabel 1. dapat diketahui bahwa hasil rata-rata pendapatan per hektare petani padi semi organik lebih besar dibandingkan rata-rata pendapatan petani padi konvensional. Hal tersebut disebabkan oleh rata-rata penerimaan petani padi semi organik lebih tinggi dibandingkan petani padi konvensional karena jumlah produksi yang dihasilkan lebih besar, meskipun total biaya yang dikeluarkan petani semi organik juga lebih tinggi. Total biaya yang dikeluarkan petani padi semi organik lebih tinggi dikarenakan pada usahatani padi semi organik menggunakan kombinasi pupuk organik dan pupuk kimia untuk memperbaiki kondisi lahan sehingga usahatani padi semi organik memerlukan biaya lebih besar untuk kebutuhan pupuk organik. Selain itu, biaya tenaga kerja pada usahatani padi semi organik juga lebih besar.

Petani padi semi organik di Desa Watukebo masih belum bisa terlepas dari penggunaan pupuk kimia secara penuh sehingga petani mengurangi pemakaian pupuk kimia secara bertahap dan disubstitusikan dengan penggunaan pupuk organik. Alasan yang melatarbelakangi petani tidak bersedia untuk menerapkan sistem pertanian organik secara langsung yaitu karena kondisi lahan yang masih bergantung terhadap pupuk kimia.

Langkah selanjutnya adalah mengetahui apakah tedapat perbedaan yang signifikan antara pendapatan petani padi semi organik dan kon- vensional di Desa Watukebo Kecamatan Blimbingsari Kabupaten Banyuwangi yang dilakukan dengan Independent Sample T Test. yang disajikan dalam tabel 2.

Berdasarkan Tabel 2 dapat diketahui bahwa nilai F-hitung yang diperoleh sebesar 0,089 dengan signifikansi 0,766 . Nilai signifikansi tersebut lebih besar dari 0,05 (Sig. 0,766>0,05) sehingga $\mathrm{H}_{0}$ diterima yang artinya tidak terdapat perbedaan varians pada data pendapatan usahatani padi semi organik dan konvensional atau dapat dikatakan kedua jenis data tersebut homogen. Berdasarkan nilai f-hitung tersebut, untuk mengetahui nilai t-hitung antara pendapatan usahatani padi semi organik dan konvensional digunakan Equal variance assumed (kedua varians data diasumsikan homogen). Nilai t-hitung yang didapatkan berada diantara $-\mathrm{t}$ tabel dan $\mathrm{t}$ tabel $(-2,04523<1,837<2,04523)$ dan nilai signifikansi 0,071. Nilai tersebut lebih besar dari 0,05 (Sig. 0,071>0,05) maka $\mathrm{H}_{1}$ ditolak, artinya tidak terdapat perbedaan yang signifikan antara pendapatan petani padi semi organik dan konvensional. Perbedaan pendapatan yang tidak signifikan tersebut diduga kuat menjadi penyebab petani belum mau beralih ke sistem semi organik karena biaya yang dikeluarkan untuk memulai usahatani padi semi organik cenderung lebih besar.

Tabel 1. Analisis Pendapatan Usahatani Padi Semi Organik dan Konvensional di Desa Watukebo Kecamatan Blimbingsari Kabupaten Banyuwangi.

\begin{tabular}{clrr}
\hline No. & \multicolumn{1}{c}{ Uraian } & Usahatani Padi Semi Organik & Usahatani Padi Konvensional \\
\hline 1 & Produksi $(\mathrm{Kg} / \mathrm{Ha})$ & $5.814,40$ & $5.559,20$ \\
2 & Penerimaan $(\mathrm{Rp} / \mathrm{Ha})$ & $24.711 .205,93$ & $22.022 .752,17$ \\
3 & Biaya & & \\
& a. Biaya Tetap (Rp/Ha) & $5.218 .900,80$ & $5.248 .123,51$ \\
& b. Biaya Variabel (Rp/Ha) & $10.687 .013,88$ & $8.749 .710,55$ \\
4 & Biaya Total $(\mathrm{Rp} / \mathrm{Ha})$ & $15.905 .914,68$ & $13.997 .834,07$ \\
5 & Pendapatan $(\mathrm{Rp} / \mathrm{Ha})$ & $8.805 .291,25$ & $8.024 .918,10$ \\
\hline
\end{tabular}

Sumber : Data Primer diolah Tahun 2018.

Tabel 2. Hasil Analisis t-hitung Pendapatan Sistem Usahatani Padi Semi Organik dan Konvensional di Desa Watukebo Kecamatan Blimbingsari Kabupaten Banyuwangi.

\begin{tabular}{llrrrrr}
\hline & f-hitung & Sig. & t-hitung & Df & Sig. (2-tailed) \\
\hline Pendapatan & $\begin{array}{l}\text { Equal variances } \\
\text { assumed } \\
\begin{array}{l}\text { Equal variances } \\
\text { not assumed }\end{array}\end{array}$ & 0,089 & 0,766 & 1,837 & 60 & 0.071 \\
\hline Sumber : Data Primer dian Tan 2018 & & & 1,837 & 59,891 & 0.071 \\
\hline
\end{tabular}

Sumber : Data Primer diolah Tahun 2018. 


\section{Perbedaan Tingkat Efisiensi Biaya Usahatani Petani Padi Sistem Semi Organik dan Petani Padi Sistem Konvensional di Desa Watukebo Kecamatan Blimbingsari Kabupaten Banyu- wangi}

Efisiensi biaya usahatani dipengaruhi besarnya penerimaan yang diperoleh serta besarnya biaya yang dikeluarkan pada setiap kali musim tanam. Penerimaan usahatani dipengaruhi oleh jumlah produksi serta harga jual yang disepakati. Alokasi biaya usahatani memerlukan pengaturan yang cermat unuk meminimumkan input usahatani. Faktor-faktor produksi yang digunakan diatur seminimal mungkin dalam rangka meningkatkan efisiensi biaya usahatani yang pada akhirnya akan meningkatkan pendapatan petani.

Tabel 3 menunjukkan rata-rata efisiensi biaya usahatani padi semi organik sebesar 1,55 yang artinya penggunaan biaya usahatani padi sistem semi organik dapat dikatakan efisien karena memiliki nilai lebih dari satu. Nilai $\mathrm{R} / \mathrm{C}$ ratio sebesar 1,55 artinya setiap pengeluaran biaya sebesar Rp 1.000,00 yang digunakan pada usahatani padi semi organik, akan memberikan hasil pada usahatani tersebut sebesar Rp 1.550,00. Rata-rata efisiensi biaya usahatani padi konvensional sebesar 1,58 yang artinya penggunaan biaya usahatani padi sistem konvensional adalah efisien karena nilainya lebih dari satu. Nilai R/C ratio sebesar 1,58 memiliki arti setiap pengeluaran biaya yang diinvenstasikan dalam usahatani padi konvensional sebesar Rp 1.000,00 akan memberikan hasil terhadap usahatani tersebut sebesar Rp 1.580,00.
Rata-rata efisiensi biaya (nilai $\mathrm{R} / \mathrm{C}$ ratio) usahatani padi semi organik lebih kecil dibandingkan rata-rata efisiensi biaya usahatani padi konvensional, namun selisih perbedaan tersebut tidak terlalu jauh. Perbedaan rata-rata efisiensi biaya usahatani antara usahatani padi semi organik dan konvensional yang kecil disebabkan oleh adanya perbedaan harga jual gabah kering sawah (GKS) di tingkat petani. Selain itu, produksi gabah semi organik dan konvensional juga tidak berbeda jauh. Rata-rata harga jual gabah beras semi organik sebesar Rp 4.250 / $\mathrm{kg}$, sedangkan untuk gabah beras konvensional memiliki rata-rata harga jual berkisar Rp 3.800 $-4.000 / \mathrm{kg}$. Petani padi semi organik langsung menjual hasil gabahnya ke kelompok dengan harga lebih tinggi sebesar Rp 200 - Rp 500 per $\mathrm{kg}$ dari gabah padi konvensional. Produksi gabah semi organik lebih tinggi dibandingkan gabah konvensional yaitu sebesar $5.814,40 \mathrm{Kg} / \mathrm{Ha}$, sedangkan gabah konvensional memiliki rata-rata produksi sebesar Rp 5.559,20 Kg/Ha.

Berdasarkan adanya perbedaan nilai efisiensi biaya usahatani tersebut, langkah selanjutnya adalah menganalisis apakah terdapat perbedaan yang signifikan antara efisiensi biaya usahatani padi semi organik dengan usahatani padi konvensional. Pengujian dilakukan menggunakan uji t sampel bebas (Independent Sample T-Test) terhadap nilai $\mathrm{R} / \mathrm{C}$ ratio pada masing-masing usahatani padi. Hasi analsis uji $t$ sampel bebas pada usahatani padi semi organik dan konvensional di Desa Watukebo Kecamatan Blimbingsari Kabupaten Banyuwangi dapat dilihat dalam tabel 4.

Tabel 3. Rata-rata Penerimaan, Biaya, dan R/C ratio Per Hektar Usahatani Padi Semi Organik dan Konvensional di Desa Watukebo Kecamatan Blimbingsari Kebupaten Banyuwangi.

\begin{tabular}{lccrr}
\hline \multicolumn{1}{c}{ Jenis Usahatani } & $\begin{array}{c}\text { Penerimaan } \\
(\mathbf{R p} / \mathbf{H a})\end{array}$ & $\begin{array}{c}\text { Biaya } \\
(\mathbf{R p} / \mathbf{H a})\end{array}$ & \multicolumn{2}{c}{ R/C } \\
& $24.711 .205,93$ & $15.905 .914,68$ & & 1,55 \\
\hline Semi Organik & $22.022 .752,17$ & $13.997 .834,07$ & & 1,58 \\
\hline
\end{tabular}

Sumber : Data Primer diolah Tahun 2018.

Tabel 4. Hasil Analisis t-hitung Rata-rata Efisiensi Biaya Usahatani Padi Semi Organik dan Konvensional di Desa Watukebo Kecamatan Blimbingsari Kabupaten Banyuwangi.

\begin{tabular}{clccccc}
\hline & & f-hitung & Sig. & t-hitung & Df & Sig. (2-tailed) \\
\hline Pendapatan & $\begin{array}{l}\text { Equal varianc- } \\
\text { es assumed } \\
\begin{array}{l}\text { Equal varianc- } \\
\text { es not assumed }\end{array}\end{array}$ & 1,807 & 0,184 & $-0,778$ & 60 & 0,440 \\
& & & & & & 0,440 \\
\hline Sumber : Data Primer diolah Tahun 2018 & & & $-0,778$ & 56,727 & \\
\hline
\end{tabular}


Berdasarkan Tabel 4 dapat diketahui bahwa nilai F-hitung efisiensi biaya usahatani padi semi organik dan konvensional sebesar 1,807 dengan signifikansi 0,184. Nilai signifikansi tersebut lebih besar dari 0,05 (Sig. 0,184>0,05) sehingga $\mathrm{H}_{1}$ ditolak, artinya kedua data tersebut homogen sehingga untuk melihat nilai t-hitung digunakan Equal variance assumed (varians data diasumsikan homogen). Berdasarkan tabel tersebut dapat diketahui nilai t-hitung berada diantara $-\mathrm{t}$ tabel dan $\mathrm{t}$ tabel $(-2,04523<-0,778$ $<2,04523$ ) dengan signifikansi 0,440 . Nilai signifikansi tersebut lebih dari 0,05 (Sig. 0,440 > $0,05)$ sehingga $H_{1}$ ditolak yang artinya tidak terdapat perbedaan yang nyata atau signifikan antara tingkat efisiensi biaya usahatani padi semi organik dan usahatani padi konvensional.

Faktor-faktor yang Mempengaruhi Produksi Usahatani Padi Semi Organik di Desa Watukebo Kecamatan Blimbingsari Kabupaten Banyuwangi

Faktor-faktor yang mempengaruhi produksi padi semi organik di Desa Watukebo dianalisis menggunakan fungsi produksi Cobb-Douglas yang terdiri dari variabel dependent (terikat) dan variabel independent (bebas). Variabel dependent yang dimaksudkan adalah variabel produksi padi semi organik (ŷ), sedangkan variabel bebas yang diduga berpengaruh terhadap produksi padi semi organik yaitu luas lahan $\left(\mathrm{x}_{1}\right)$, jumlah benih $\left(\mathrm{x}_{2}\right)$, urea $\left(\mathrm{x}_{3}\right)$, phonska $\left(\mathrm{x}_{4}\right)$, pupuk organik $\left(\mathrm{x}_{5}\right)$, agensia hayati $\left(\mathrm{x}_{6}\right)$, dan tenaga kerja (HKP) $\left(\mathrm{x}_{7}\right)$.

Variabel-variabel bebas tersebut harus memenuhi pengujian asumsi klasik yang terdiri dari dari pengujian terhadap multikolinearitas, heteroskedastisitas, dan normalitas. Berikut ini merupakan penjelasan tentang hasil uji asumsi klasik terhadap faktor-faktor yang mempengaruhi produksi padi semi organik di Desa Watukebo Kecamatan Blimbingsari Kabupaten Banyuwangi.
Tabel 5. Hasil Uji Asumsi Klasik Terhadap Faktor-faktor yang Mempengaruhi Produksi Padi Semi Organik di Desa Watukebo Kecamatan Blimbingsari.

\begin{tabular}{lcr}
\hline \multirow{2}{*}{ Model } & \multicolumn{2}{c}{ Correlations } \\
\cline { 2 - 3 } (Constant) & Tolerance & \multicolumn{1}{c}{ VIF } \\
\hline Lahan & 0,058 & 17,367 \\
Benih & 0,153 & 6,540 \\
Urea & 0,165 & 6,043 \\
Phonska & 0,407 & 2,458 \\
Pupuk Organik & 0,542 & 1,845 \\
Agensia Hayati & 0,271 & 3,695 \\
Tenaga Kerja & 0,052 & 19,035 \\
\hline Sumber: Data Primer Diolah Tahun 2018
\end{tabular}

Sumber : Data Primer Diolah Tahun 2018.

Penjelasan kemungkinan terjadinya gangguan dalam model berdasarkan Tabel 5 adalah sebagai berikut:

\section{Uji Multikolinearitas}

Uji Multikolinearitas digunakan untuk menguji ada tidaknya hubungan yang sempurna antar variabel bebas dalam model regresi. Cara yang digunakan untuk mengetahui adanya gejala multikolinearitas adalah dengan melihat nilai tolerance $(<0,10)$ dan nilai VIF ( $>10)$. Hasil analisis regresi produksi padi semi organik menunjukkan bahwa terdapat gejala multikolinearitas yang ditunjukkan dengan nilai VIF lahan dan tenaga kerja yang lebih besar dari 10. Langkah selanjutnya yang dapat dilakukan adalah dengan membuag variabel yang memiliki nilai VIF terbesar yaitu tenaga kerja sehingga didapatkan model persamaan sebagai berikut:

Tabel 6. Hasil Uji Asumsi Klasik Terhadap Faktor-faktor yang Mempengaruhi Produksi (Iterasi 2) Padi Semi Organik di Desa Watukebo Kecamatan Blimbingsari.

\begin{tabular}{lcc}
\hline \multirow{2}{*}{ Model } & \multicolumn{2}{c}{ Correlations } \\
\cline { 2 - 3 } (Constant) & Tolerance & VIF \\
Lahan & 0,123 & 8,120 \\
Benih & 0,205 & 4,885 \\
Urea & 0,170 & 5,886 \\
Phonska & 0,458 & 2,186 \\
Pupuk Organik & 0,543 & 1,843 \\
Agensia Hayati & 0,272 & 3,674 \\
\hline Sumber : Data Primer Diolah Tahun 2018.
\end{tabular}


Berdasarkan Tabel 6 dapat diketahui bahwa seluruh variabel bebas dalam model telah terbebas dari gejala mutikolineraitas. Hal tersebut ditunjukkan dengan nilai VIF seluruh variabel kurang dari 10. Hasil dari iterasi tersebut menunjukkan bahwa variabel yang terlibat dalam model produksi padi semi organik di Desa Watukebo Kecamatan Blimbingsari Kabupaten Banyuwangi terdiri dari luas lahan $\left(\mathrm{x}_{1}\right)$, jumlah benih $\left(\mathrm{x}_{2}\right)$, urea $\left(\mathrm{x}_{3}\right)$, phonska $\left(\mathrm{x}_{4}\right)$, pupuk organik $\left(\mathrm{x}_{5}\right)$, agensia hayati $\left(\mathrm{x}_{6}\right)$.

\section{Uji Heteroskedastisitas}

Gejala heteroskedastisitas dalam model regresi dapat dilihat dengan adanya titik-titik yang membentuk pola tertentu pada grafik scatter plot. Titik-titik di daerah scatter plot harus menyebar dan tidak membentuk suatu pola tertentu. Hasil analisis menunjukkan bahwa pola penyebaran data tidak membentuk pola tertentu dalam scatter plot sehingga model persamaan tidak mengalami heteroskedastistias.

\section{Uji Normalitas}

Kriteria pengujian uji normalitas dapat dilakukan dengan melihat grafik P-Plot dimana dalam grafik tersebut terdapat titik-titik yang menyebar dan mengikuti sepanjang garis diagonal. Data dapat dikatakan tidak normal apabila titik-titik tersebut berada jauh dari garis diagonal. Asumsi normalitas diperlukan terutama untuk statistik parametrik seperti analisis regresi berganda. Hasil analisis menunjukkan bahwa penyebaran data berada dekat di sekitar garis diagonal sehingga dapat disimpulkan bahwa data telah berdistribusi normal.

Berdasarkan hasil pengujian asumsi klasik tersebut, dapat diketahui bahwa dari ketujuh variabel yang diuji, hanya ada enam variabel yang lulus dari uji asumsi klasik yaitu luas lah- an (x1), jumlah benih (x2), urea (x3), phonska $(\mathrm{x} 4)$, pupuk organik (x5), agensia hayati (x6). Keenam variabel tersebut kemudian dianalisis menggunakan regresi linier berganda.

Berdasarkan hasil analisis terhadap faktor-faktor yang mempengaruhi produksi padi semi organik, terjadi beberapa gangguan pada permodelan sehingga dilakukan iterasi model dengan membuang variabel tenaga kerja sehingga didapatkan model persamaan sebagai berikut:

$$
\begin{aligned}
\log (\hat{y})= & 3,074+0,770 \log \left(x_{1}\right)+0,089 \log \left(x_{2}\right) \\
& -0,140 \log \left(x_{3}\right)-0,028\left(x_{4}\right)+0,220\left(x_{5}\right) \\
& +0,100\left(x_{6}\right)+\varepsilon
\end{aligned}
$$

Sehingga model fungsi produksi Cobb-douglass dari hasil transformasi nilai Log tersebut adalah:

$$
\hat{y}=1185,77 x_{1}^{0,770} x_{2}^{0,089} x_{3}^{(-0,140)} x_{4}^{(-0,028)} x_{5}^{0,220}
$$

Keterangan :

$\hat{y}=$ Produksi padi transisi organik $(\mathrm{kg})$

$\mathrm{x}_{1}=$ Luas lahan $(\mathrm{Ha})$

$\mathrm{x}_{2}=\operatorname{Benih}(\mathrm{Kg})$

$\mathrm{x}_{3}=$ Urea $(\mathrm{Kg})$

$\mathrm{x}_{4}=$ Phonska $(\mathrm{Kg})$

$\mathrm{x}_{5}=$ Pupuk organik $(\mathrm{Kg})$

$\mathrm{x}_{6}=$ Agensia Hayati (Liter)

\section{a. Uji F}

Uji F digunakan untuk mengetahui pengaruh masing-masing variabel bebas secara simultan. Berdasarkan hasil analisis diperoleh nilai signifikansi Uji F sebesar 0,000 pada taraf kepercayaan $95 \%$ yang artinya bahwa variabel bebas (luas lahan, benih, urea, phonska, pupuk organik, dan agensia hayati) secara simultan berpengaruh terhadap variabel produksi padi semi organik.

Tabel 7. Hasil Analisis Faktor-faktor yang Mempengaruhi Produksi (Iterasi 2) Padi Semi Organik di Desa Watukebo Kecamatan Blimbingsari Kabupaten Banyuwangi.

\begin{tabular}{lcrrr}
\hline \multicolumn{1}{c}{ Variabel Bebas } & Koef. Regresi & Nilai Koef. Regresi & t-hitung & \multicolumn{1}{c}{ Sig. } \\
\hline Lahan & $\mathrm{x}_{1}$ & 0,770 & 9,125 & $0,000^{*}$ \\
Benih & $\mathrm{x}_{2}$ & 0,089 & 1,507 & 0,145 \\
Urea & $\mathrm{x}_{3}$ & $-0,140$ & $-2,324$ & $0,029^{*}$ \\
Phonska & $\mathrm{x}_{4}$ & $-0,028$ & $-0,455$ & 0,653 \\
Pupuk organik & $\mathrm{x}_{5}$ & 0,220 & 6,698 & $0,000^{*}$ \\
Agensia hayati & $\mathrm{x}_{6}$ & 0,100 & 1,790 & $0,086^{* *}$ \\
\hline Sig. Uji F & 0,000 & & & \\
Konstanta & 3,074 (Anti Log =1185,77) & & & \\
Adjusted $\mathrm{R}^{2}$ & 0,973 & & & \\
Sumber : Data Primer Diolah Tahun 2018.
\end{tabular}




\section{b. Uji Determinasi}

Hasil analisis berdasarkan Tabel 7 menunjukkan nilai Adj. $\mathrm{R}^{2}$ sebesar 0,973 atau 97,3\% yang artinya produksi padi semi organik dipengaruhi oleh variabel luas lahan, benih, urea, phonska, pupuk organik, dan agensia hayati sebesar $97,3 \%$ sedangkan sisanya sebesar $2,7 \%$ dipengaruhi oleh variabel lain di luar model.

c. Uji t

Berdasarkan Tabel 7 dapat diketahui bahwa produksi padi semi organik apabila tidak terdapat penambahan variabel luas lahan, benih, urea, phonska, pupuk organik, dan agensia hayati sebesar $1185,77 \mathrm{~kg}$. Selain itu, berdasarkan tabel tersebut dapat diketahui pula nilai elastisitas produksi sebesar 1,011 yang artinya secara umum usahatani padi semi organik di Desa Watukebo Kecamatan Blimbingsari Kabupaten Banyuwangi berada kondisi Increasing Return to Scale. Pada model fungsi produksi Cobb Douglas, nilai koefisien regresi dari setiap variabel bebas menunjukk nilai elastisitas masing-masing penggunaan faktor produksi. Hasil analisis signifikansi dan elastisitas faktor-faktor produksi usahatani padi semi organik adalah:

\section{Luas Lahan}

Variabel luas lahan berpengaruh positif dan signifikan pada tingkat kepercayaan $95 \%$. Nilai regresi luas lahan adalah sebesar 0,770 . Hal ini menunjukkan bahwa setiap penambahan sebesar 1\% luas lahan akan meningkatkan produksi sebesar $0,770 \%$ dengan asumsi ceteris paribus. Berdasarkan hasil penelitian diketahui bahwa rata-rata luas lahan yang dimiliki petani sebesar $0,96 \mathrm{Ha}$ dengan produksi rata-rata sebesar $5814,40 \mathrm{~kg} / \mathrm{Ha}$. Dengan demikian petani perlu menambah luas lahan untuk meningkatkan produksi. Semakin luas jumlah lahan yang digunakan maka semakin tinggi hasil produksi yang dihasilkan.

\section{Benih}

Variabel benih bertanda positif namun tidak signifikan pada tingkat kepercayaan 95\%. Nilai elastisitas benih dalam fungsi produksi sebesar 0,089 yang artinya penambahan atau pengurangan jumlah benih sebesar $1 \%$ tidak akan meningkatkan ataupun mengurangi jumlah produksi padi sebesar $0,089 \%$.

3. Urea

Penggunaan urea mempunyai pengaruh negatif dan signifikan terhadap produksi padi pada taraf kepercayaan $95 \%$. Setiap penambahan pupuk urea sebesar $1 \%$ akan menurunkan produksi sebesar $0,140 \%$. Penggunaan urea yang terlalu banyak akan menurunkan hasil produksi karena semakin banyak kandungan pupuk kimia yang masuk akan menyebabkan penurunan kesuburan tanah yang pada akhirnya akan menurunkan produksi padi. Pengaruh negatif yang dihasilkan pupuk urea diduga karena kondisi tanah yang digunakan dalam budidaya tanaman padi semi oganik telah berangsur subur sehingga penambahan pupuk urea justru akan menurunkan hasil produksi.

\section{Phonska}

Penggunaan pupuk phonska mempunyai pengaruh negatif namun tidak signifikan terhadap produksi padi pada taraf kepercayaan 95\%. Koefisien regresi phonska sebesar $-0,028$ artinya setiap penambahan input produksi phonska sebesar $1 \%$ tidak akan menurunkan ataupun menurunkan produksi sebesar $0,028 \%$. Kondisi lahan padi semi organik di Desa Watukebo telah berangsur pulih dari kandungan bahan kimia sehingga penambahan pupuk phonska tidak akan menurunkan hasil produksi padi semi organik .

\section{Pupuk Organik}

Penggunaan pupuk organik mempunyai pengaruh positif dan signifikan terhadap produksi padi pada taraf kepercayaan $95 \%$. Koefisien regresi pupuk organik sebesar 0,220 bertanda positif yang artinya setiap penambahan $1 \%$ luas lahan akan meningkatkan produksi sebesar 0,220\% dengan asumsi ceteris paribus. Pupuk organik memiliki banyak manfaat bagi pertumbuhan tanaman, tidak terkecuali tanaman padi. Penambahan pupuk organik pada usahatani padi semi organik akan dapat memulihkan kondisi kesuburan tanah akibat penggunaan pupuk kimia yang berlebihan. Bahan-bahan organik yang terkandung dalam pupuk organik akan menyebabkan jasad renik atau mikroorganisme menguntungkan bagi tanaman akan kembali berkembang sehingga tanah menjadi subur dan unsur hara kembali tersedia bagi tanaman.

\section{Agensia Hayati}

Penggunaan agensia hayati mempunyai pengaruh positif dan signifikan terhadap produksi padi pada taraf kepercayaan $90 \%$. Koefisien regresi agensia hayati sebesar 0,100 artinya setiap penambahan $1 \%$ agensia hayati akan meningkatkan produksi sebesar $0,100 \%$ dengan asumsi ceteris paribus. Agensia hayati merupakan pestisida organik yang digunakan sebagai pengganti pestisida kimia sehingga tidak berbahaya bagi ekosistem sekitar. Penggunaan agensia hayati 
akan berpengaruh positif terhadap hasil produksi karena agensia hayati berfungsi untuk mengendalikan organisme pengganggu tanaman tanpa merusak ekosistem di sekitarnya sehingga bersifat ramah lingkungan.

Faktor-faktor yang Mempengaruhi Produksi Usahatani Padi Konvensional di Desa Watukebo Kecamatan Blimbingsari Kabupaten Banyuwangi

Faktor-faktor yang mempengaruhi produksi padi konvensional di Desa Watukebo terdiri dari variabel dependent (terikat) dan variabel independent (bebas). Variabel dependent yang dimaksudkan adalah variabel produksi padi konvensional $(\hat{y})$, sedangkan variabel bebas yang diduga berpengaruh terhadap produksi padi semi organik yaitu luas lahan $\left(\mathrm{x}_{1}\right)$, jumlah benih $\left(\mathrm{x}_{2}\right)$, pupuk kimia $\left(\mathrm{x}_{3}\right)$, pestisida $\left(\mathrm{x}_{4}\right)$, dan tenaga kerja $\left(\mathrm{x}_{5}\right)$.

Variabel-variabel bebas tersebut harus memenuhi pengujian asumsi klasik yang terdiri dari dari pengujian terhadap multikolinearitas, heteroskedastisitas, dan normalitas. Berikut ini merupakan penjelasan tentang hasil uji asumsi klasik terhadap faktor-faktor yang mempengaruhi produksi padi konvensional.

Tabel 8. Hasil Uji Asumsi Klasik Terhadap Faktor-faktor yang Mempengaruhi Produksi Padi Konvensional di Desa Watukebo Kecamatan Blimbingsari.

\begin{tabular}{lrr}
\hline \multirow{2}{*}{\multicolumn{1}{c}{ Model }} & \multicolumn{2}{c}{ Correlations } \\
\cline { 2 - 3 } & \multicolumn{1}{c}{ Tolerance } & \multicolumn{1}{c}{ VIF } \\
\hline (Constant) & & \\
Luas Lahan & 0,032 & 31,711 \\
Benih & 0,177 & 5,642 \\
Pupuk Kimia & 0,307 & 3,256 \\
Pestisida & 0,670 & 1,492 \\
Tenaga Kerja & 0,037 & 28,863 \\
\hline Sumber : Data Primer Diolah Tahun 2018
\end{tabular}

\section{Uji Mutikolinearitas}

Hasil analisis regresi produksi padi konvensional menunjukkan bahwa terdapat gejala multikolinearitas yang ditunjukkan dengan nilai VIF lahan dan tenaga kerja yang lebih besar dari 10. Langkah selanjutnya yang dapat dilakukan adalah dengan membuang variabel yang memiliki nilai VIF terbesar yaitu luas lahan.

Berdasarkan Tabel 9 dapat diketahui bahwa seluruh variabel bebas dalam model telah ter- bebas dari gejala mutikolineraitas. Hal tersebut ditunjukkan dengan nilai VIF seluruh variabel kurang dari 10. Hasil dari iterasi tersebut menunjukkan bahwa variabel yang terlibat dalam model produksi padi semi organik di Desa Watukebo Kecamatan Blimbingsari Kabupaten Banyuwangi terdiri dari jumlah benih $\left(\mathrm{x}_{2}\right)$, pupuk kimia $\left(\mathrm{x}_{3}\right)$, pestisida $\left(\mathrm{x}_{4}\right)$, dan tenaga kerja $\left(\mathrm{x}_{5}\right)$.

Tabel 9. Hasil Uji Asumsi Klasik Terhadap Faktor-faktor yang Mempengaruhi Produksi (Iterasi 2) Padi Semi Organik di Desa Watukebo Kecamatan Blimbingsari.

\begin{tabular}{|c|c|c|}
\hline \multirow{2}{*}{ Model } & \multicolumn{2}{|c|}{ Correlations } \\
\hline & Tolerance & VIF \\
\hline \multicolumn{3}{|l|}{ (Constant) } \\
\hline Benih & 0,201 & 4,981 \\
\hline Pupuk Kimia & 0,318 & 3,142 \\
\hline Pestisida & 0,679 & 1,473 \\
\hline Tenaga Kerja & 0,177 & 5,658 \\
\hline
\end{tabular}

\section{Uji Heteroskedastisitas}

Hasil analisis menunjukkan bahwa pola penyebaran data tidak membentuk pola tertentu dalam scatter plot sehingga dapat disimpulkan model persamaan terbebas dari gejala heteroskedastisitas.

\section{Uji Normalitas}

Hasil analisis menunjukkan bahwa penyebaran data berada dekat di sekitar garis diagonal sehingga dapat disimpulkan bahwa data telah berdistribusi normal.

Berdasarkan hasil pengujian asumsi klasik tersebut, dapat diketahui bahwa dari kelima variabel yang diuji, hanya ada empat variabel yang lulus dari uji asumsi klasik yaitu benih $\left(\mathrm{x}_{2}\right)$, pupuk kimia $\left(\mathrm{x}_{3}\right)$, pestisida $\left(\mathrm{x}_{4}\right)$, dan tenaga kerja $\left(\mathrm{x}_{5}\right)$. Keempat variabel tersebut kemudian dianalisis menggunakan regresi linier berganda.

Berdasarkan hasil analisis terhadap faktor-faktor yang mempengaruhi produksi padi semi organik, terjadi beberapa gangguan pada permodelan sehingga dilakukan iterasi model dengan membuang variabel tenaga kerja sehingga didapatkan model persamaan sebagai berikut:

$$
\begin{aligned}
\log (\hat{y})= & 2,053+0,153 \log \left(x_{2}\right)+0,048 \log \left(x_{3}\right) \\
& -0,016 \log \left(x_{4}\right)+0,822 \log \left(x_{5}\right)+\varepsilon
\end{aligned}
$$

Sehingga model fungsi produksi Cobb-douglass dari hasil transformasi nilai Log tersebut adalah :

$$
\hat{\mathrm{y}}=112,98 \mathrm{x}_{2}{ }^{0,153} \mathrm{x}_{3}{ }^{0,048} \mathrm{x}_{4}{ }^{(-0,016)} \mathrm{x}_{5}{ }^{0,822} \mathrm{e}^{\varepsilon}
$$


Keterangan :

$\hat{\mathrm{y}} \quad=$ Produksi padi konvensional $(\mathrm{kg})$

$\mathrm{x} 2=$ Jumlah benih $(\mathrm{Kg})$

$\mathrm{x} 3=$ Pupuk kimia $(\mathrm{Kg})$

$\mathrm{x} 4=$ Pestisida (Liter)

$\mathrm{x} 5=$ Tenaga kerja (HKP)

$\mathrm{e} \quad=$ Tingkat kesalahan

\section{a. Uji F}

Berdasarkan hasil analisis anova pada Tabel 11 diperoleh hasil nilai $\mathrm{F}$ tabel sebesar 160,303 dengan nilai signifikansi sebesar 0,000 pada taraf kepercayaan yang artinya bahwa variabel bebas (benih, pupuk kimia, pestisida, dan tenaga kerja) secara simultan berpengaruh terhadap variabel produksi padi konvensional.

b. Uji Determinasi

Hasil analisis berdasarkan Tabel 11 menunjukkan nilai Adj. $\mathrm{R}^{2}$ sebesar 0,955 atau 95,5\% yang artinya produksi padi dipengaruhi oleh variabel benih, pupuk kimia, pestisida, dan tenaga kerja sebesar 95,5\% sedangkan sisanya sebesar $4,5 \%$ dipengaruhi oleh variabel lain di luar model.

c. Uji $\mathrm{t}$

Berdasarkan Tabel 11 dapat diketahui bahwa produksi padi konvensional apabila tidak terdapat penambahan variabel benih, pupuk kimia, pestisida, dan tenaga kerja sebesar 112,98 $\mathrm{kg}$. Selain itu, berdasarkan tabel tersebut dapat diketahui pula nilai elastisitas produksi sebesar 1,007 yang artinya secara umum usahatani konvensional di Desa Watukebo Kecamatan Blimbingsari Kabupaten Banyuwangi berada kondisi Increasing Return to Scale. L Hasil analisis signifikansi dan elastisitas faktor-faktor produksi usahatani padi konvensional adalah :

1. Benih

Variabel benih berpengaruh positif dan signifikan pada tingkat kepercayaan 95\%. Koefisien regresi benih sebesar 0,153 artinya setiap penambahan input produksi benih sebesar $1 \%$ akan meningkatkan produksi sebesar $0,153 \%$ dengan asumsi cateris paribus. Penggunaan benih berpengaruh nyata terhadap hasil produksi padi konvensional sehingga jumlah benih masih perlu ditingkatkan untuk memaksimalkan produksi padi konvensional. Namun, penggunaan jumlah benih juga harus diperhatikan. Benih yang terlalu banyak akan menyebabkan tanaman kekurangan nutrisi untuk pertumbuhannya sehingga menyebabkan tanaman tidak dapat tumbuh dengan maksimal.

\section{Pupuk Kimia}

Variabel pupuk kimia bertanda positif namun tidak berpengaruh nyata terhadap produksi padi konvensional. Koefisien regresi pupuk kimia sebesar 0,048 artinya setiap penambahan input produksi benih sebesar $1 \%$ tidak akan meningkatkan ataupun menurunkan produksi sebesar $0,048 \%$ dengan asumsi cateris paribus. Penggunaan pupuk kimia tidak berpengaruh nyata terhadap produksi padi sehingga penggunaan pupuk kimia dapat dikurangi seiring waktu untuk menuju sistem pertanian semi organik.

\section{Pestisida}

Variabel pestisida mempunyai tanda negatif dan tidak berpengaruh secara nyata pada tingkat kepercayaan 95\%. Koefisien regresi pestisida sebesar $-0,016$ artinya setiap penambahan pestisida sebesar $1 \%$ tidak akan menurunkan ataupun meningkatkan produksi sebesar $0,016 \%$ dengan asumsi cateris paribus. Penggunaan pestisida memberikan pengaruh negatif terhadap produksi padi konvensional diduga karena bahan-bahan kimia yang terkandung dalam pestisida menurunkan kesuburan tanah.

\section{Tenaga Kerja}

Variabel tenaga kerja mempunyai tanda positif dan berpengaruh secara nyata pada tingkat kepercayaan $95 \%$. Koefisien regresi tenaga kerja sebesar 0,822 artinya setiap penambahan input

Tabel 10. Hasil Analisis Faktor-faktor yang Mempengaruhi Produksi (Iterasi 2) Padi Konvensional di Desa Watukebo Kecamatan Blimbingsari Kabupaten Banyuwangi.

\begin{tabular}{lcrrrc}
\hline \multicolumn{1}{c}{ Variabel Bebas } & Koef. Regresi & Nilai Koef. Regresi & t-hitung & \multicolumn{1}{c}{ Sig. } & VIF \\
\hline Benih & $\mathrm{x}_{2}$ & 0,153 & 2,221 & $0,035^{*}$ & 4,981 \\
Pupuk kimia & $\mathrm{x}_{3}$ & 0,048 & 0,943 & 0,354 & 3,142 \\
Pestisida & $\mathrm{x}_{4}$ & $-0,016$ & $-0,608$ & 0,548 & 1,473 \\
Tenaga kerja & $\mathrm{x}_{5}$ & 0,822 & 8,342 & $0,000^{*}$ & 5,658 \\
\hline Konstanta & $2,053$ (Anti $\log =112,98)$ & & & & \\
Adjusted $\mathrm{R}^{2}$ & 0,955 & & & & \\
Sumber : Data Primer Diolah Tahun 2018 & & & &
\end{tabular}


produksi benih sebesar $1 \%$ akan meningkatkan produksi sebesar $0,822 \%$ dengan asumsi cateris paribus. Kegiatan usahatani padi tidak terlepas dari peran tenaga kerja dalam menjalankan usahataninya sehingga penggunaan tenaga kerja perlu ditingkatkan yang diiringi dengan peningkatan modal usahatani.

\section{KESIMPULAN}

Berdasarkan hasil penelitian yang dilakukan, keraguan petani dalam menerapkan pertanian padi semi organik disebabkan oleh tidak adanya perbedaan yang signifikan antara rata-rata pendapatan petani padi semi organik dan petani padi konvensional di Desa Watukebo Kecamatan Blimbingsari Kabupaten Banyuwangi. Selain itu, berdasarkan hasil penelitian juga diketahui tidak terdapat perbedaan yang signifikan antara rata-rata tingkat efisiensi biaya usahatani padi semi organik dan konvensional di Desa Watukebo Kecamatan Blimbingsari Kabupaten Banyuwangi.

Faktor-faktor yang berpengaruh secara nyata terhadap usahatani padi semi organik adalah luas lahan, pupuk urea, dan pupuk organik, sedangkan jumlah benih, pupuk phonska, dan agensia hayati tidak berpengaruh secara nyata pada usahatani padi semi organik.

Faktor-faktor yang berpengaruh nyata terhadap usahatani padi konvensional adalah jumlah benih dan tenaga kerja, sedangkan pupuk kimia dan pestisida tidak berpengaruh secara nyata.

\section{DAFTAR PUSTAKA}

Herawati, Noknik Karliya., J. Hendrani, dan S. Nugraheni. 2014. Viabilitas Pertanian Organik dibandingkan dengan Pertanian Konvensional. Laporan Akhir Penelitian Viabilitas Pertanian Organik.

Heryanto, Mahra Arari., Y. Sukayat, dan D. Supyandi. 2016. Model Perilaku Petani dalam Adopsi Sistem Usahatani Padi Organik : Paradoks SosialEkonomi-Lingkungan. Jurnal Sosiohumaniora, vol. 18(2) : 159 165.

Khorniawati, Melisa. 2014. Produk Pertanian Organik di Indonesia : Tinjauan atas Preferensi Konsumen Indonesia Terhadap Produk Pertanian Organik Lokal. Jurnal Studi Manajemen, vol. 8(2) : $171-182$.
Kompas.com. (2016, February 12) . Tiga Varietas Padi Organik Banyuwangi Resmi Terdaftar di Kementerian Pertanian. [Serial Online]. https://biz.kompas.com/ $\mathrm{read} / 2016 / 12 / 02 / 174807728 /$ tiga.varietas. padi.organik.banyuwangi.resmi.terdaftar. di.kementerian.pertanian. Tanggal Akses : 13 Juli 2018.

Kusumo, Rani andriani Budi., A. Chareina, A. H. Sadeli, dan G. W. Mukti. 2017. Persepsi Petani Terhadap Teknologi Budidaya Sayuran Organik di Kabupaten Bandung Barat. Jurnal Paspalum, vol. 5(2) : 19-27.

Lesmana, Dina., dan Margareta. 2017. Tingkat Pengetahuan Petani Padi Sawah (Oryza sativa L.) Terhadap Pertanian Organik di Desa Manunggal Jaya Kecamatan Tenggarong Seberang. Jurnal Pertanian Terpadu, vol. 5(2): $8-33$.

Mayrowani, Henny. 2012. Pengembangan Pertanian Organik di Indonesia. Forum Penelitian Agro Ekonomi, vol. 30(2) : 91 - 108.

Mungara, Evan., D. Indradewa, dan R. Rogomulyo. 2013. Analisis Pertumbuhan dan Hasil Padi Sawah (Oryza sativa L.) Pada Sistem Pertanian Konvensional, Transisi Organik, dan Organik. Jurnal Vegetalika, vol. 2(3) : 1-12.

Safitri, Sri Ariani. 2013. Strategi Pengembangan Sistem Agribisnis Beras Organik (Studi Kasus : Desa Lubuk Bayas, Kecamatan Perbaungan, Kabupaten Serdang Bedagai). Skripsi. Medan : Fakultas Pertanian Universitas Sumatera Utara.

Soekartawi. 1995. Analisis Usahatani. Jakarta : Universitas Indonesia.

Sugiyono. 2013. Statistika Untuk Penelitian. Bandung : Alfabeta.

Zuriah, Nurul. 2005. Metodologi Penelitian Sosial dan Pendidikan. Jakarta : Bumi Aksara. 